\title{
Meaningful English Teaching in Light of Piaget, Vygotski, Wallon and Ausubel
}

\section{Carla Cruz Rosa Pires de Souza ${ }^{1}$, José Carlos Rosa Pires de Souza ${ }^{2}$, Guilherme Amorim Noleto Cabral ${ }^{3}$, Vítor Cruz Rosa Pires de Souza ${ }^{4}$, Vitória Siufi Zandoná4, Bruno Massayuki Makimoto Monteiro²}

\author{
${ }^{1}$ Catholic University Dom Bosco (UCDB), Campo Grande, MS, Brazil \\ ${ }^{2}$ State University of Mato Grosso do Sul (UEMS), Campo Grande, MS, Brazil \\ ${ }^{3}$ Federal University of Mato Grosso do Sul (UFMS), Campo Grande, MS, Brazil \\ ${ }^{4}$ University for the Development of the State and Region of the Pantanal (Uniderp), Campo Grande, MS, Brazil \\ Email:carla.cruz05@hotmail.com, josecarlossouza@uol.com.br,gcabral8@gmail.com, \\ crpsvitor@gmail.com,vizandona@gmail.com,brunoftmakimoto@hotmail.com
}

How to cite this paper: de Souza, C. C. R. P., de Souza, J. C. R. P., Cabral, G. A. N., de Souza, V. C. R. P., Zandoná, V. S., \& Monteiro, B. M. M. (2021). Meaningful English Teaching in Light of Piaget, Vygotski, Wallon and Ausubel. Creative Education, 12, 212-219. https://doi.org/10.4236/ce.2021.121016

Received: December 19, 2020

Accepted: January 23, 2021

Published: January 26, 2021

Copyright $\odot 2021$ by author(s) and Scientific Research Publishing Inc. This work is licensed under the Creative Commons Attribution International License (CC BY 4.0).

http://creativecommons.org/licenses/by/4.0/

\begin{abstract}
The English teaching provides the learner with new opportunities for knowledge, work, communication and more. This must be as conscious as possible, with didactic and pedagogical, cognitive and metacognitive strategies, aimed at seeking better results. The aim is to discuss English language teaching with playfulness, in light of main theories of Piaget, Vygotsky, Wallon and Ausubel, making it as meaningful as possible. As results and discussion, it emphasizes that the teaching of so-called foreign languages, such as English, is conscious and needs didactic and pedagogical strategies that involve the learner in his in its multiple contexts, making his programmatic content interesting and motivating for those who learn it. For Piaget, this learning must be according to the student's age group, their interactions and adaptations; Vygotsky argues the need for social interaction; Wallon involves the affective and motivating question and Ausubel defends the valorization of the student's previous knowledge. Thus, it is stated that English teaching should be stimulated as soon as possible, in the youngest age groups, so it can be assimilated and learned in a playful, social, interactive and meaningful way.
\end{abstract}

\section{Keywords}

English, Knowledge, Learning, Teaching Method

\section{Introduction}

In order to better understand the teaching process of a new language, it is necessary, initially, to distinguish what comes to be acquisition and learning. Kra- 
shen, in the 1980s, distinguished these terms with the idea, still contemporary today, that they underlie research and communicative teaching methods. Among other aspects, he defined only his mother tongue as acquired, while the others would be learned. The first definitely marks the individual, being assimilated unconsciously, without extensive knowledge of his grammar and spelling; so-called foreign languages are learned in formal contexts, consciously, and students are not immersed in the context of their speakers (Coracini, 2014).

The efficient teaching of the English language must be as conscious as possible, with didactic and pedagogical, cognitive and metacognitive strategies, aimed at the search for more and better results. To this end, it can be complemented by playful and significant determinants, integrating the apprentices, according to their age groups, in their social and cultural context, as well as involving their affective and interactionist contents. In this regard, this study aims to discuss the main ideas and theories of Piaget, Vygotsky, Wallon and Ausubel, relating them to teaching with playfulness of the English language, aiming to make it as meaningful as possible.

\section{Method}

A quantitative study was carried out, through a narrative bibliographic review, with articles published in the last 10 years (2010-2020), in Portuguese or in other languages. The bibliographic databases used were National Library of Medicine (PubMed), Scientific Electronic Library Online (SciELO), Lilacs, SCOPUS, Capes Journals Portal, SBU, Google Scholar and Psyinfo. The terms "Language arts", "teaching", "deep learning", "PIAGET, JEAN", "VYGOTSKY, LEV SEMENO-VICH", "WALLON, HENRI" were used as descriptors and the boolean AND.

Once the articles were raised, the title and abstract were read, if not in accordance with the objective of the present study, they were excluded. Therefore, a line of narrative reasoning was drawn that encompassed the study theme. Following, three topics were listed, considered coherent and didactic, starting with the conceptions of Jean William Fritz Piaget, the main ideas of Lev SemionovitchVigotski, Henri Paul Hyacinthe Wallon and his theory, significant learning and David Paul Ausubel and, finally, social, interactive, playful and meaningful teaching of the English language.

It is important to note that bibliographic review articles are essential to deepen the scientific debate, as well as to expose a more complete perception about the intended theme (Depolito et al., 2020). The narrative-type review is well accepted in the scientific community; however, it receives some criticism because it cannot be replicated; however, this type of review requires less time and provides faster dissemination of knowledge (Rother, 2007).

\section{Result and Discussion}

\subsection{Conceptions of Jean William Fritz Piaget}

How does knowledge emerge and evolve? For Piaget it is impossible to separate 
organic growth from the child's psychological development process. He was also intimately convinced that such knowledge could only have one legitimate path: the scientific method (Piaget, 1950), through these concepts develops and creates constructivism.

In this theory, he realized that there are factors responsible for cognitive development: 1) Biological factor: organic growth and maturation of the nervous system; 2) Factor of experience and exercises: the child's interaction with objects; 3) Factor of social interactions: through language and education; 4) Imbalance of actions: adaptation to the environment and situations (Fossile, 2010).

Thus, the child is influenced by these factors during what Piaget calls sequential cognitive stages, divided into: 1$)$ Sensory-motor ( 0 - 2 years): the child finds biological and cognitive balance; 2) Preoperative (2 - 7 years): development of symbolic capacity; 3) Concrete operative (7 - 12 years): more logical thinking; 4) Formal operative (12 years onwards): hypothetical-detective reasoning (de Abreu et al., 2010).

From these stages he observed that learning begins with the imbalance between the subject and the new object, going through three stages: 1) Assimilation: incorporating the new into existing ideas; 2) Accommodation: modification of the schemes previously established to deal with the new information; 3) Adaptation: balance between the previous stages, constantly adapting to the impositions of the environment (Ferracioli, 1999).

Therefore, for Piaget, each person actively builds knowledge and interaction with the environment and the educator helps this process, not dictating pre-established truths, but providing an education focused on the subject's autonomy.

\subsection{Main ideas of Lev Semenovitch Vigotski}

For Vygotsky, the human being is characterized by a primary sociability (Ivic, 2010). The psychic world is seen as a historical and social construction, as an active and social being, the subject is built by relations with the other and with the environment, so the psychological cannot be separated from what it is material and social.

Thought, in turn, takes shape in the patterns of the individual's culture, so the junction between culture, environment and social relations results in thinking. So how does the individuality of the subject emerge? Through the appropriation of the external world through social relations. It is a constant exchange and mutual transformation between individual and external environment.

In addition, Vygotsky saw development divided into two different and complementary parts, which are maturation and learning. That is the creator of capacities that make learning possible, this would be the act of learning itself. However, each individual is unique in his way of learning, so the thinker cites three levels of development.

The level of real development, at which independent problem solving occurs, 
and the level of potential development, where problem solving occurs under the guidance of an adult or in collaboration with more capable companions gives rise to the zone of proximal development (ZDP) (Vygotsky, 1991).

Thus, the educator enters this ZDP, to assist the student in functions that are not yet mature and that should be stimulated, in this sense, pedagogical intervention is important to direct development.

\subsection{Henri Paul Hyacinthe Wallon and His Theory}

Wallonian theory considers that the development of the human being is integrated with the environment in which he lives and also with the affective and motor aspects; being, therefore, essentially psychogenetic and sociocultural, in addition to being relativistic, with broad organic bases. In this way, the focus is on the integration between organisms and the environment in which individuals are immersed; and between the cognitive, affective and motor dimensions in the constitution of the person. Therefore, the being is understood as the result of this interaction between its dimensions, which develop in the integration of its organic bases with the environment, predominantly with the social environment to which they belong (Fraga, 2018).

Taking Wallon's theory into account, better results are obtained in absorbing information and elaborating knowledge when mixing theory and practical applications of what is studied. For example, in the case of the English language, when putting the child in contact with the language, resources such as books and handouts would not be used, but some experiences such as games and jokes, in which only English could be used for the Communication. Or, to use simulations of situations, such as taking children to a supermarket to learn the names of fruits and vegetables, asking prices and even learning the monetary system of a country, which has English as its mother tongue.

Also supported by Wallon's idea, interaction activities with the family and society can be included, as also defended by Galvão (1995) that "For man, society is an organic necessity that determines his development and, therefore, his intelligence. Man is social and this is an internal need", or to take cultural trips and outings; all of these strategies have proven benefits in the practice of teaching and learning the foreign language. The student is more motivated, shows more interest in the content and still learns in a more pleasant and fun way, besides showing more confidence when he needs to use the language in real situations.

In moments, dominantly, affective of development, what is in the foreground is the construction of the subject, which is done through interaction with others of greater cognitive weight; the object and the external reality that are modeled at the expense of the acquisition of the techniques elaborated by the culture. Both processes are, therefore, social, although in different senses: in the first, social is synonymous with interpersonal; in the second, it is the cultural equivalent. Each new moment will have incorporated the acquisitions made at the previous level, that is, in the other dimension. This means that affectivity depends, in 
order to evolve, on achievements made in the field of intelligence and vice versa (de La Taille et al., 2019).

This back-and-forth that characterizes human development is presented by Wallon as a progression from the syncretic form to the child's differentiated form, when relating to the world and with himself, being thenon-linear path, but alternating between the internal and external (Fraga, 2018).

\subsection{Deep Learning and David Paul Ausubel}

American psychologist David Ausubel has made many contributions to understanding learning as meaningfully and efficiently as possible, which are applied both in the exact, social, educational areas, among others. Its Theory of Cognitive Assimilation (TAC) aims to expand the knowledge capacity of the student's cognitive structure, through intentional production and the use of advanced organizers, which are prior to the new knowledge to be acquired. This previous knowledge Ausubel called subsunitors; with these peculiarities, learning would become significant and not mechanical. TAC provides practical methods for meaningful learning, such as the advanced organizer strategy, which organizes and reorganizes new knowledge; the strategy of progressive differentiation, which reduces the difficulty of complex and abstract knowledge; the implementation of the advanced organizer's strategy and the integrative reconciliation strategy forms the concept map. All of these work together with metacognition (Tian et al., 2020).

The teaching of the English language has the possibility of having its significance and importance greatly improved depending on various aspects, such as the stimulus and technical and pedagogical preparation of the teacher, the student's prior knowledge, the potentially significant didactic and instructional materials, in addition to of the student's willingness to learn. The latter has to share his previous experiences in his native language, with the possibility and the certainty that the new language will bring many uses in his daily life (Agra et al., 2019).

Ausubel's ideas further valued contemporary discoveries in the area of cognitive and metacognitive psychology. There is empirical evidence that the psychic function cognition, human development and the neurobiology of knowledge provide relationships between concept-based teaching, meaningful learning and knowledge sharing. Concept-based teaching, initially previous, is a pedagogy found to improve knowledge transfer. This comes from a constructivist teaching and learning paradigm; Ausubel's theory of meaningful learning and its construct of substantive knowledge integration provide a model to help educators understand, implement and evaluate concept-based teaching. The student, in turn, is an active agent and co-responsible for his teaching-learning process.

\subsection{Social, Interactive, Playful and Meaningful Teaching of the English Language}

The human learning process relies on the interaction of executive, cognitive, af- 
fective, psychomotor, sensoperceptive, orientative, intellectual, mnemic mental functions, among others; these, together, bring together the various concepts in coherent and as abstract abstractions as possible and, if the sub-subsectors are used, the greater the significance of this knowledge acquired for the actors in question. According to the ideas of David Ausubel, the previous experiences of the English language learner, regardless of their age group, will be essential in the setting of voluntary attention (concentration or focus) and, therefore, of anterograde (for recent facts) and retrograde (for past facts) (Ramos, 2014).

Associated to this fact, playfulness accompanies a social representation of something pleasurable and that optimizes time; and, the more motivation and personal satisfaction the student has with the English language, the greater cognitive ability he will have to learn an increasing amount of knowledge. Corroborating the teachings of Jean Piaget, the human capacity to learn is born and develops with it, and does not come ready; the English teacher will be a learning facilitator if he knows how to ponder his pedagogical and didactic strategies in an evolutionary aspect, equally valuing in each student, individually, his cognitive, affective, integrative, historical, social and cultural potentials (de Abreu et al., 2010). Vygotsky would emphasize here the importance of the exchange of information between student-teacher-student, in search of a mutual transformation between them and the environment (Ivic, 2010), and in a context as dynamic and affective as Wallon would defend (Fraga, 2018).

The phrase by Getha-Eby et al. (2014), which places the student as an active andco-responsible agent for his learning process, is the basis for a more social, interactive, playful and meaningful teaching of the English language. When leading the classes, English students showed greater ease, pleasure and speed in learning. This protagonism is acquired when the teacher prepares the classes aiming to put the student in an active situation for learning, not only absorbing information and absolute truths, but building his own knowledge, with the help of the educator and the environment, just as Piaget defends being a more efficient means of teaching (de Abreu et al., 2010).

For that, the classes they have to be dynamic, with activities that put students to use the content they are learning, not only decorate it, but experience it. In the teaching practice of the English language, teaching phrases in the past by observing, studying and reflecting on how the Egyptians lived, in the past, is an example that brought positive results in the classroom. The student was interested and attentive from the beginning, when videos and images with the content were presented, throughout the process, he actively participated bringing all the luggage he had, adding curiosities, observations and additional information. Finally, a mummy salty recipe with sausage was added to the lesson plan, a totally practical class, in which the student was faced with culinary vocabularies.

Already with adult students, it is observed in English classes, a better productivity when teaching grammatical parts of the language related to a subject of interest, such as bringing texts about your profession, vocabularies of your hob- 
bies, asking and discussing current issues, among others. This makes learning meaningful, and the student makes relationships to absorb it.

In order to take advantage of all the ideas of the authors that are mentioned in this article, and to reach a level of efficiency in learning the English language, it is necessary to think about each student or group individually; each individual's individuality, tastes, activities, travel, stories must be relevant, in short, all the baggage and qualities they carry. Thus, the foreign language will be a pleasant and meaningful part in the life of each person, who goes to the classes of a teacher who manages to unite the methods, rules and practices, with the social, individual and the active.

As to practical implications, a better performance is highlighted in terms of linguistic resourcefulness, since theory and practice have been combined, i.e., learning has been brought into the student's daily life. This fact contributes to the application of the content learned and constructed throughout the classes. Knowing about this is important, as the educational methods that language teachers can use in teaching are expanded.

\section{Conclusion}

It is possible to teach the English language with a variety of didactic and pedagogical strategies, involving the subject and his/her social environment in this process; one must take into account their previous knowledge, their history, culture, neurobiological conditions, age group, emotions and motivation. The learner will be the main social agent in this context, being co-responsible for his process of acquiring new knowledge; the English teacher will have the role of facilitator, being able to use playfulness to make learning as complete and meaningful as possible.

\section{Conflicts of Interest}

The authors declare no conflicts of interest regarding the publication of this paper.

\section{References}

Agra, G., Formiga, N. S., Oliveira, P. S. D., Costa, M. M. L., Fernandes, M. D. G. M., \& Nóbrega, M. M. L. D. (2019). Análisis del concepto de Aprendizaje Significativo bajo la luz de la Teoría de Ausubel. Revista Brasileira de Enfermagem, 72, 248-255. https://doi.org/10.1590/0034-7167-2017-0691

Coracini, M. J. (2014). Between Acquiring and Learning a Language: Subjectivity and Polyphony. Bakhtiniana: Revista de Estudos do Discurso, 9, 4-24. https://doi.org/10.1590/S2176-45732014000200002

De Abreu, L. C., de Oliveira, M. A., de Carvalho, T. D., Martins, S. R., Gallo, P. R., \& Reis, A. O. A. (2010). A epistemologia genética de Piaget e o construtivismo. Journal of Human Growth and Development, 20, 361-366. https://doi.org/10.7322/jhgd.19973

De La Taille, Y., De Oliveira, M. K., \& Dantas, H. (2019). Piaget, Vigotski, Wallon: Teorias psicogenéticas em discussão. Summus editorial. 
Depolito, S. C. P., de Moraes, L. L., Siqueira, W. G., Baquião, L. S. M., da Cunha Januário, G., \& Morceli,G. (2020). Atuação da equipe de enfermagem frente ao desmame precoce: Uma revisão narrativa. Saúde Coletiva (Barueri), 10, 2915-2924. https://doi.org/10.36489/saudecoletiva.2020v10i55p2915-2924

Ferracioli, L. (1999). Aspectos da construção do conhecimento e da aprendizagem na obra de Piaget. Caderno Brasileiro de Ensino de Física, 16, 180-194.

Fossile, D. K. (2010). Construtivismo versus sócio-interacionismo: Uma introdução às teorias cognitivas. Alpha, 11, 105-17.

Fraga, A. B. M. (2018). Henri Wallon e a Educação Contemporânea.

Galvão, I. (1995). Henri Wallon: Uma concepção dialética do desenvolvimento infantil. Vozes.

Getha-Eby, T. J., Beery, T., Xu, Y., \& O’Brien, B. A. (2014). Meaningful Learning: Theoretical Support for Concept-Based Teaching. Journal of Nursing Education, 53, 494-500. https://doi.org/10.3928/01484834-20140820-04

Ivic, I. (2010). Lev Semenovich Vygotsky. Tradução: José EustáquioRomão. Org: Edgar Pereira Coelho.

Piaget, J. (1950). Discours du directeur du Bureau international d'éducation.

Ramos, A. S. D. F. (2014). Dados recentes da neurociência fundamentam o método “Brain-basedlearning”. Revista Psicopedagogia, 31, 263-274.

Rother, E. T. (Ed.) (2007). Systematic Literature Review $\times$ Narrative Review. Acta Paulista de Enfermagem, 20, 5-6. https://doi.org/10.1590/S0103-21002007000200001

Tian, Z., Zhang, K., Zhang, T., Dai, X., \& Lin, J. (2020). Application of Ausubel Cognitive Assimilation Theory in Teaching/Learning Medical Biochemistry and Molecular Biology. Biochemistryand Molecular BiologyEducation, 48, 202-219. https://doi.org/10.1002/bmb.21327

Vygotsky, L. S. (1991). A formação social da mente (4th ed.). Tradução: José Cipolla Neto, Luis Silveira Menna Barreto, Solange Castro Afeche. São Paulo: Livraria Martins Fontes Editora Ltda. 